\title{
Hubungan Adiksi Internet dengan Status Gizi pada Mahasiswa Fakultas Kesehatan Masyarakat Universitas Airlangga
}

\author{
Relationship of Internet Addiction with Nutritional Status of Students Faculty \\ of Public Health, Airlangga University
}

Harun Kurniawan*1, Farapti $^{1}$

\begin{abstract}
ABSTRAK
Latar Belakang: Penggunaan Internet yang berlebihan saat ini menyebabkan masalah yang disebut Internet Addiction Disorder (IAD) atau kecanduan internet. Adiksi internet adalah seseorang yang tidak mampu mengontrol diri untuk menggunakan internet, yang dapat menyebabkan gangguan kesehatan fisik, psikis, maupun kemampuan sosialisasi, dam perubahan pola makan yang mengakibatkan berubahan status gizi. Akses internet yang mudah merupakan faktor utama dalam kecanduan internet dan dapat mengubah gaya hidup. Karena kampus menyediakan fasilitas Internet gratis dan tidak ada pengawasan orang tua, risiko masalah penggunaan Internet mahasiswa meningkat.

Tujuan: Tujuan dari penelitian ini adalah mempelajari hubungan adiksi internet dengan status gizi pada mahasiswa Fakultas Kesehatan Masyarakat, Universitas Airlangga

Metode: Penelitian ini termasuk jenis penelitian obeservasional analitik dengan desain studi cross-sectional. Sampel penelitian ini adalah mahasiswa Fakultas Kesehatan Masyarakat Universitas Airlangga sebanyak 72 mahasiswa. Pengumpulan data adiksi internet menggunakan kuesioner young's internet addiction test, status gizi menggunakan perhitungan indeks massa tubuh melalui pengukuran berat badan serta tinggi badan dan analisis data menggunakan uji korelasi spearman.

Hasil: Hasil penelitian menunjukkan terdapat hubungan antara adiksi internet dengan status gizi $(p=0,020$; $\mathrm{r}=-0,274)$. Berdasarkan penelitian ini, diketahui bahwa semakin seseorang adiksi terhadap internet maka akan semakin tinggi tingkat status gizinya.

Kesimpulan: Kesimpulan pada penelitian ini adalah adanya hubungan negatif yang lemah antara adiksi internet dengan status gizi. Hubungan negatif menunjukkan bahwa semakin seseorang memiliki adiksi pada internet yang tinggi maka semakin rendah status gizinya. Penggunaan internet sebaiknya dibatasi terutama pada area kampus dengan cara membatasi akses wi-fi gratis yang hanya dapat digunakan untuk kebutuhan studi, sehingga dapat mencegah terjadinya permasalahan kesehatan secara psikis dan fisik.
\end{abstract}

Kata kunci: adiksi internet, status gizi, mahasiswa

\section{ABSTRACT}

Background: The current excessive use of the internet can cause a problem called Internet Addiction Disorder (IAD) or internet addiction. Internet addiction is defined as someone unable to control himself to use the internet, which can cause physical, psychological, and social health problems, and dietary changes resulting in changes in nutritional status. Easy internet access is a major factor in internet addiction and can change a lifestyle. Students have an increased risk of internet use problems due to free internet facilities on the campus and no parental supervision. The purpose of this study was to study the relationship between internet addiction and nutritional status.

Objectives: The purpose of this study was to observe the relationship between internet addiction and the nutritional status of Public Health students, Airlangga University.

Methods: This research is an analytic observational study with a cross-sectional study design. The sample of this research is 72 students of the Faculty of Public Health, Airlangga University. Internet addiction data collection used a questionnaire of Young's internet addiction test, nutritional status using body mass index 
calculation through measurement of body weight and height, and data analysis using the Spearman correlation test.

Results: The results showed that there was a relationship between internet addiction and nutritional status ( $p=$ 0.020; $r=-0.274$ ). Based on this research, is known the higher a person is addicted to the internet, the higher the level of nutritional status.

Conclusions: This study concludes a weak negative relationship between internet addiction and nutritional status. The negative relationship indicates that the more someone is addicted to the internet, the lower the nutritional status.

Keywords: internet addiction, nutritional status, college student

\author{
*Koresponden: \\ haruun07@gmail.com \\ Harun Kurniawan \\ Departemen Gizi, Fakultas Kesehatan Masyarakat, Universitas Airlangga, Kampus C Mulyorejo, 60115, \\ Surabaya, Jawa Timur, Indonesia
}

\title{
PENDAHULUAN
}

Internet pada saat ini menjadi salah satu sumber ilmu pengetahuan serta dapat melakukan hal lainnya seperti mendapatkan informasi terbaru, berkomunikasi, dan menjadi sarana hiburan (Khan, Shabbir, dan Rajput, 2017). Berdasarkan data laporan Digital Global Overview 2020, Penggunaan internet di Dunia memiliki waktu rata-rata 6 jam 43 menit per hari, sedangkan saat ini Indonesia memiliki rata - rata waktu penggunaan internet selama 7 jam 59 menit per hari, serta menduduki peringkat ke delapan dunia (Kemp, 2020). Pada saat ini penggunaan internet lebih banyak digunakan untuk sarana entertainment seperti, games online dan media sosial (Kuss, Griffiths, dan Binder, 2013).

Penggunaan internet dapat memberikan dampak positif pada penggunanya apabila digunakan secara bijak. Namun, penggunaan internet memiliki berbagai dampak negatif seperti kecanduan internet, menganggu kegiatan belajar, penipuan, kejahatan secara daring, merupakan kemampuan interaksi sosial, menimbulkan sikap hedonisme dan konsumtif serta akses pornografi. Penggunaan internet dapat menyebabkan bentuk baru dari adiksi yaitu kecanduan internet. Kecanduan internet dapat terjadi pada siapa saja terutama pada remaja, karena remaja berada pada tahap pencarian jati diri, memiliki rasa keingin tahuan yang lebih besar, mudah terpengaruh oleh teman serta ingin mencoba hal baru (Simanjuntak, 2020).

Penggunaan internet yang berlebih saat ini dapat menyebabkan suatu permasalahan yang disebut Internet Addiction Disorder (IAD) atau adiksi terhadap internet (Khan, Shabbir, dan Rajput, 2017). Internet Addiction Disorder didefinisikan adalah seseorang yang tidak mampu mengontrol diri untuk menggunakan internet, yang dapat menyebabkan gangguan kesehatan fisik, psikis, maupun kemampuan sosialisasi (Naseri et al., 2015). Dengan berkembangnya teknologi saat ini untuk menggunakan internet sangat mudah melalui smart phone atau tablets. Mudahnya akses internet tersebut merupakan faktor utama dari Internet Addiction Disorder dan dapat merubah sebuah gaya hidup (Wu et al., 2015).

Usia mahasiswa strata-1 (S1) umumnya sekitar 18 - 24 tahun, usia tersebut merupakan merupakan usia dewasa awal. Berdasarkan data yang dikumpulkan oleh Asosiasi Penyelenggara Jasa Internet Indonesia pada tahun 2018, kelompok usia dengan tingkat penggunaan internet tertinggi adalah 15-24 tahun. Menurut pernyataan itu. Berdasarkan pernyataan $\mathrm{Li}$ et al (2016), mahasiswa memiliki peningkatan risiko masalah penggunaan internet dikarenakan adanya fasilitas internet bebas pakai di kampus serta tidak dapat pengawasan dari orang tua. Adiksi pada internet dapat menyebabkan masalah kesehatan mental (Young, 2017). Menurut Zoer et al., (2011) sebanyak 29\% permasalahan kesehatan mental terjadi pada saat $22-35$ tahun.

Internet Addiction Disorder erat kaitannya dengan kegiatan yang lebih melibatkan duduk atau tidur, sehingga dapat memicu perilaku sedentari. perilaku sedentari menyebabkan penurunan pada tingkat aktivitas fisik seseorang. Tingkat aktivitas fisik yang rendah dapat meningkatkan resiko kejadian obesitas yang menjadi salah satu faktor pendukung terjadinya penyakit Non Communicable Diseases (NCD) dengan tingkat kematian tinggi seperti penyakit jantung koroner, diabetes, dan hipertensi (Lapousis, 2016). Aktivitas fisik juga sering dikaitkan dengan tingkat kebugaran pada seseorang, berdasarkan penelitian (Murbawani dan Firiana, 2017) menunjukkan hubungan yang signifikan aktivitas fisik dengan kebugaran jasmani. Latihan fisik dan olahraga teratur dapat meningkatkan kebugaran dan mempeangaruhi status gizi (Widodo, 2013).

Seseorang dengan waktu penggunaan internet yang berlebih diyakini memiliki pola makan yang tidak teratur. IAD (Internet Addiction Disorder) mempengaruhi status gizi dengan melibatkan pola makan yang cenderung berbeda dengan orang yang tidak mengalami IAD (Kim et al., 2010). Pola makan yang baik penting dalam pencegahan penyakit ketika dewasa. Pola makan yang buruk dapat menyebabkan kekurangan nutrisi, yang 
dapat menyebabkan kekurangan energi dan masalah nutrisi lainnya. Pola makan yang tidak tepat juga dapat menyebabkan obesitas dan meningkatkan risiko penyakit degeneratif seperti diabetes, hipertensi, malnutrisi, dan sindrom metabolik. (Simanjuntak, 2020).

Status gizi dapat dipengaruhi oleh banyak faktor. Termasuk genetika, gaya hidup, pola makan dan lingkungan. Faktor keturunan yang mempengaruhi status gizi seseorang dikarenakan, Orang tua yang obesitas lebih cenderung memiliki keturunan yang gemuk, begitu pula sebaliknya. Faktor gaya hidup, pola makan dan lingkungan pada umumnya dapat mengakibatkan perbedaan jumlah asupan sat gizi yang dikonsumsi. Hal tersebut dikarenakan adanya paparan sosial yang dapat mempengaruhi pola makan seseorang (Muchilsa, Citrakesumasari, danIndrisari, 2013). Penelitian yang dilakukan oleh Goldfield et al., (2010) menyatakan bahwa perempuan cenderung berupaya mengurangi berat badannya untuk menyamai tokoh yang diidolakannya di media. Pada saat ini media sangat mudah diakses dikarenakan mudahnya untuk mengakses internet.

Berdasarkan hal tersebut, peneliti tertarik melakukan penelitian untuk menganalisis hubungan adiksi internet dengan status gizi mahasiswa Fakultas Kesehatan Masyarakat Universitas Airlangga.

\section{METODE}

Jenis penelitian yang dilakukan adalah observasional analitik dengan desain studi Cross-Sectional yaitu pengambilan data dengan dilakukan sekali tanpa adanya intervensi. Populasi penelitian merupakan mahasiswa strata-1 reguler Fakultas Kesehatan Masyarakat yang terdiri dari dua program studi yaitu Kesehatan Masyarakat dan Gizi di Universitas Airlangga dengan jumlah 1135 mahasiswa. Pengambilan sampel menggunakan teknik purposive sampling. Peneliti telah menetapkan kriteria inklusi dan eksklusi. Mahasiswa yang bersedia menjadi responden dan dalam keadaan sehat dijadikan kriteria inklusi, dan mahasiswa dengan riwayat penyakit menular, minum minuman keras dan merokok menjadi kriteria eksklusi penelitian ini. Berdasarkan kriteria inklusi dan eksklusi yang telah ditetapkan oleh peneiti dan dihitung menggunakan rumus pengambilan sampel Lemeshow jumlah sampel yang didapatkan sebesar 72 responden.

Variabel yang digunakan dalam penelitian ini meliputi tingkat adiksi internet dan status gizi mahasiswa. Pengambilan data dilakukan dengan cara pengisian kuisioner young's internet addiction test, hasil pengisian kuisioner akan dihitung dan dikelompokkan untuk mengetahui tingkat adiksi internet pada responden. Responden dengan nilai kuisioner 0 - 19 diartikan tidak memiliki adiksi pada internet, 20 - 49 adiksi ringan, 50 - 79 adiksi sedang, dan nilai lebih dari 80 berarti adiksi berat. Pengukuran antropometri yang meliputi berat badan dan tinggi badan, selanjutnya dilakukan penghitungan indeks massa tubuh untuk mengetahui status gizi responden. Pengumpulan data dilakukan self-administerd untuk mendapatkan data karakteristik responden dan tingkat adiksi internet. Pengumpulan data status gizi dilakukan dengan pengukuran atropometeri. Pengolahan data dilakukan melalui editing, scoring, coding dan entry. Analisis data dalam penelitian ini menggunakan uji korelasi Spearman untuk mengetahui hubungan antara variabel tingkat kecanduan internet dan variabel status gizi.

Pengambilan data dilakukan pada bulan Agustus - Oktober 2020 untuk pengisian kuesionare dilakukan secara daring, pengambilan data antropometeri dilakukan dengan 2 cara yaitu secara daring dan tatap muka. Pengambilan data daring didampingi oleh peneliti melalui video call untuk melakukan pengukuran dan tatap muka dilakukan dengan mematuhi protokol kesehatan COVID-19. Penelitian ini telah mendapat izin etik dari Komisi Etik Fakultas Kedokteran Gigi Universitas Airlangga dengan nomor 373/HRECC.FODM/VIII/2020 .

\section{HASIL DAN PEMBAHASAN}

Tabel 1. Distribusi Karakteristik Responden

\begin{tabular}{llc}
\hline Karakteristik & Frekuensi (n) & \% \\
\hline Jenis Kelamin & & 22,2 \\
Laki-Laki & 16 & 77,8 \\
Perempuan & 56 & 100,0 \\
\hline Total & 72 & 20,8 \\
\hline Usia (Tahun) & 15 & 26,4 \\
\hline 19 & 19 & 25,0 \\
20 & 18 & 25,0 \\
21 & 18 & 2,8 \\
22 & 2 & 100,0 \\
23 & 72 & \\
\hline Total & & $20,3 \pm 1,156$ \\
\hline Rata-rata Usia \pm SD
\end{tabular}


Responden penelitian merupakan mahasiswa strata-1 pada Fakultas Kesehatan Masyarakat Universitas Airlangga. Karakteristik responden dalam penelitian ini meliputi jenis kelamin dan usia. Distribusi karakteristik responden dapat dilihat pada tabel 1 . Sebagian besar responden $(77,2 \%)$ memiliki jenis kelamin perempuan. Usia responden pada penelitian ini memiliki rata-rata 20,3 \pm 1.156 tahun. Penelitian ini melibatkan mahasiswa sebagai responden. Penelitian yang dilakukan oleh Young (2017), 13\% dari 531 mahasiswa University Of Texas memperlihatkan tanda-tanda ketergantungan internet, dan (Yang, 2001) di University of Taiwan memperkirakan bahwa 10\% mahasiswa memenuhi kriteria adiksi terhadap internet. Menurut Young (2017) mahasiswa lebih cenderung mengakses internet dan menggunakannya yang kemudian berkontribusi pada tingkat penggunaan internet yang lebih adiktif di kampus. Rentang usia tersebut juga merupakan permulaan dari tahap dewasa awal dimana diperlukan pemenuhan zat gizi yang seimbang dalam membangun kualitas sumber daya manusia yang baik agar terhindar dari penyakit degeneratif dan terhindar dari penurunan produktifitas kerja (Adriani dan Wirjatmadi, 2012). Periode kritis dalam perubahan perilaku terutama pada kebiasaan makan, cenderung terjadi pada kehidupan mahasiswa dengan adanya paparan terhadap kondisi stress, penggunaan internet, dan kekurangan waktu dalam mengimplementasikan kebiasaan makan yang sehat (Kim et al., 2010).

Tabel 2. Distribusi Tingkat Adiksi Internet Responden

\begin{tabular}{lcc}
\hline Tingkat Adiksi Internet & Frekuensi (n) & \% \\
\hline Ringan & 44 & 61,1 \\
Sedang & 26 & 36,1 \\
Berat & 2 & 2,8 \\
\hline Total & 72 & 100,0 \\
\hline Rata-rata \pm SD & & $46,76 \pm 11,508$ \\
\hline
\end{tabular}

Tingkat adiksi internet didapatkan melalui kuisioner young's internet addiction test. Hasil dari pengisian kuisioner disesuaikan dengan penilaian yang sudah ditentukan pada young's internet addiction test dengan skala nilai 20-49 merupakan adiksi ringan, 50-79 adiksi sedang, dan 80-100 adiksi berat. Tabel 2 menunjukkan bahwa Sebagian besar $(61,1 \%)$ responden penelitian memiliki tingkat adiksi ringan dan terdapat $2,8 \%$ memiliki tingkat adiksi internet yang berat. Rata-rata nilai responden sebesar 46,76 \pm 11.508 . Internet Addiction Disorder atau adiksi terhadap internet merupakan sindrom yang ditandai dengan ketidak mampunya seseorang mengontrol diri untuk menggunakan internet. Pada penelitian ini tingkat adiksi internet responden dinilai dari Young's Internet Addiction Test untuk mengevaluasi tingkat adiksi internet. Rareta tingkat adiksi internet responden $61,1 \%$ tergolong adiksi ringan, $36,1 \%$ tergolong sedang, dan 2,8\% tergolong berat.

Adiksi Internet disebut juga dengan pathological internet use atau compulsive internet use. Kecanduan internet adalah ketidakmampuan seseorang untuk mengontrol penggunaan internetnya, yang dapat menyebabkan masalah psikologis, sosial, dan pekerjaan dalam kehidupan pribadinya. (Young, 2017). Individu dapat menggunakan internet lebih dari 20 jam dalam satu minggunya. Menurut Young (2017) adiksi internet terbagi dengan beberapa jenis menurut aktivitasnya seperti Cybersexual Addiction dimana kecenderungan penggunaan internet digunakan untuk berselancar ke situs-situs untuk melihat hal-hal yang berkaitan dengan seksualitas, Cyber-Relationship Addiction perilaku ini mengacu pada indivitu yang gemar mencari atau berkenalan dengan orang melalui internet, Net - Compulsion merupakan penggunaan internet untuk berjudi, berbelanja maupun perdagangan online, Information Overload dimana seseorang menggunakan internet yang bersifat kompulsif, dan Computer Addiction pengguna internet berperilaku obsesif terhadap permainan online..

Aspek orang yang kecanduan internet sebenarnya hampir sama dengan jenis kecanduan lainnya, namun Asian Journal of Health and Information Science memasukkan kecanduan internet dalam kategori psikologis, bukan kecanduan fisik (Rinhard et al., 2019). Disebutkan bahwa kecanduan internet mencakup empat aspek yaitu: paksaan (terus-menerus melakukan), penarikan (penarikan diri), toleransi (toleransi), masalah internasional dan yang berhubungan dengan kesehatan (masalah hubungan interpersonal dan kesehatan)(Simanjuntak, 2020). Orang yang kecanduan internet biasanya lupa apa yang harus dilakukan dan memilih untuk terus berselancar di internet, adapun dampak negatif dari terus berinternet termasuk membuangbuang waktu. Hal ini sesuai dengan pernyataan Soetjipto (2015) bahwa kecanduan internet akan meningkatkan waktu yang dihabiskan dan akan sangat sering menggunakan internet sehingga menimbulkan berbagai masalah.

Menurut sebuah studi oleh Asosiasi Pengembangan Internet Pemuda China (Thomala, 2021), pengguna internet di atas 24 tahun menyumbang $83 \%$ dari total jumlah pengguna Internet di China. Di antara mereka, $6 \%$ atau 10 juta adalah pecandu berat. Berbeda dengan (Mak et al., 2014) melakukan penelitian lain di 6 negara asia pada tahun 2013 - 2014 . Mereka mensurvei 5366 responden yang menggunakan young's internet addiction test. Tes tersebut mendapatkan 14,95\% responden menderita adiksi internet. Berdasarkan hal tersebut, dapat disimpulkan bahwa prevalensi kecanduan internet sangat bervariasi di berbagai budaya dan masyarakat. Sebagian alasannya adalah para peneliti menggunakan berbagai alat untuk mendefinisikan kecanduan internet, sehingga sulit untuk menemukan konsistensi antar studi. 
Tabel 3. Distribusi Status Gizi Responden

\begin{tabular}{llc}
\hline Status Gizi & Frekuensi (n) & \% \\
\hline Kurus & 19 & 26,4 \\
Normal & 36 & 50,0 \\
BB Lebih & 17 & 23,6 \\
\hline Total & 72 & 100,0 \\
\hline
\end{tabular}

Tabel 3 menunjukkan bahwa status gizi sebagian besar responden (50\%) normal, 26,4\% kurang gizi, dan 23,6\% gizi lebih. Berbagai faktor-faktor seperti asupan gizi dan aktivitas fisik akan memberikan dampak pada kondisi status gizi seseorang. Status gizi dapat dilihat dengan berbagai indikator seperti Indeks Massa Tubuh (IMT), lemak masa tubuh, dan indikator lainnya. Pada penelitian ini menggunakan IMT sebagai indikator penentu status gizi seseorang (Poetry, 2019).

Status gizi mengacu pada kondisi fisik akibat makan dan mendapat gizi yang cukup. Jika seseorang dapat mencukupi konsumsi, maka risiko gangguan kesehatannya rendah, sehingga dapat beraktivitas secara maksimal. Sebaliknya jika zat gizi yang dikomsumsi tidak dapat terpenuhi atau melebihi batas, maka tubuh akan berdadaptasi untuk mencapai keadaan homeostatis sehingga fungsi fisiologisnya dapat terganggu (Adriani dan Wirjatmadi, 2012).

Status gizi seseorang dapat dipengaruhi dengan aktivitas fisik. Asupan zat gizi yang berlebihan dan tidak diimbangi aktivitas yang cukup akan menyebabkan terjadinya peningkatan berat badan, sehingga dapat mempengaruhi status gizi seseorang (Nova dan Yanti, 2017). Ketidak seimbangan asupan gizi dan aktivitas fisik, ditambah dengan perubahan pola makan yang dikarenakan adiksi internet dapat menimbulkan masalah gizi (Kim et al., 2010).

Jenis kelamin menjadi penentu jumlah energi dan zat gizi yang dibutuhkan karena terdapat perbedaan proses pertumbuhan dan perkembangan individu laki- laki dan perempuan (Adriani dan Wirjatmadi, 2012). Lakilaki cenderung membutuhkan lebih banyak energi dibandingkan perempuan. Hal tersebut disebabkan oleh jumlah dan intensitas aktivitas fisik yang dilakukan laki-laki lebih banyak dibandingkan perempuan, sehingga kebutuhan energi laki-laki lebih banyak. Pada usia dewasa, kebutuhan zat gizi juga berbeda sesuai dengan jenis kelamin karena perbedaan komposisi tubuh serta jenis aktivitas fisik yang dilakukan (Brown, 2019).

Latihan fisik merupakan salah satu alasan yang dapat mempengaruhi status gizi seseorang. Kurangnya latihan fisik dapat menyebabkan obesitas atau status gizi orang yang kelebihan berat badan. Hal ini disebabkan karena berlebihnya penumpukan asupan zat gizi didalam tubuh sehingga menyebabkan tidak adanya pembakaran kalori yang disebabkan oleh tidak adanya aktivitas fisik yang dilakukan(Murbawani dan Firiana, 2017).

Berdasarkan hasil penelitian ini didapatkan prevalensi status gizi kurus, normal, dan berat badan lebih secara berturut-turut lebih pada responden mahasiswa dalam penelitian ini adalah 26,4\%, 50\%, 23,6\%. Prevalensi responden berstatus gizi normal masih paling tinggi, namun prevalensi responden dengan status gizi berat badan lebih juga cukup besar. Jika dibandingkan dengan profil kesehatan jawa timur 2018, prevalensi gemuk pada Mahasiswa Fakultas Kesehatan Masyarakat Universitas Airlangga ini bahkan lebih tinggi dari pada prevalensi di jawa timur yaitu sebesar 16\%. (Dinas Kesehatan Jawa Timur, 2019). Dalam penelitian yang dilakukan oleh Poetry (2019) yang dilakukan pada 65 Mahasiswa Fakultas Kesehatan Masyarakat Universitas Airlangga didapatkan prevalensi status gizi kurus sebesar 18,5\%, normal 44,6\%, dan 36,9\% berat badan lebih. Jika dibandingan dengan penelitian tersebut ditemukan perbedaan yang cukup signifikan pada status gizi berat badan lebih yang didapatkan dalam penelitian ini lebih rendah dan lebih tinggi pada status gizi kurus.

Hubungan antara adiksi internet dengan status gizi pada Mahasiswa Fakultas Kesehatan Masyarakat Universitas Airlangga dapat ditinjau berdasarkan hasil tabulasi silang antara dua variabel dan uji statistik dengan uji Spearman. Hasil analisis hubungan adiksi internet dengan status gizi dapat dilihat pada Tabel 4.

Tabel 4 menunjukkan bahwa sebagian besar responden yang memiliki adiksi internet dengan status gizi normal sebesar 50\% responden. Berdasarkan analisis dengan uji statistik Spearman didapatkan nilai signifikansi sebesar 0,020 ( $\mathrm{p}$-value $=0,020$ ). nilai tersebut $<0,05$ sehingga adanya hubungan antara tingkat adiksi internet dengan status gizi. Nilai korelasi hubungan ini adalah -0,274 yang memiliki hubungan korelasi negatif yang cukup. Korelasi negatif menunjukkan bahwa semakin tinggi tingkat kecanduan internet responden maka status gizinya semakin berkurang atau semakin kurus, begitu pula sebaliknya. Semakin rendah tingkat kecanduan internet responden maka status gizinya semakin baik atau normal. 
Tabel 4. Analisis Hubungan Adiksi Internet Dengan Status Gizi dengan uji Spearman

\begin{tabular}{lcccccc}
\hline & \multicolumn{3}{c}{ Tingkat Adiksi Internet } & & & Total \\
Status Gizi & Ringan & Sedang & Berat & & p-value & r \\
& $\boldsymbol{\%}$ & $\boldsymbol{\%}$ & $\boldsymbol{\%}$ & & & \\
\hline Kurus & 9,7 & 13,9 & 2,8 & 26,4 & & \\
Normal & 34,7 & 15,3 & 0,0 & 50,0 & 0,020 & $-0,274$ \\
BB Lebih & 16,7 & 6,9 & 0,0 & 23,6 & & \\
\hline
\end{tabular}

Hasil penelitian menunjukkan hubungan yang signifikan antara adiksi internet dengan status gizi dengan arah hubungan negatif yang lemah $(\mathrm{p}=0,020 \mathrm{r}=-0,274)$. Hal tersebut tidak sejalan dengan studi pertama yang meneliti hubungan tersebut antara adiksi internet dengan status gizi yang menyatakan bahwa seseorang yang adiksi terhadap internet memiliki risiko tinggi terjadinya kenaikan berat badan dan status gizi (Lajunen et al., 2007). Sama halnya dengan Canan et al (2014) dalam penelitiannya menyatakan hal yang serupa yaitu terdapatnya hubungan positif antara adiksi internet dengan status gizi. Pada penelitian tersebut menemukan penggunaan internet untuk berselancar, menonton video secara daring, mengakses forum, aplikasi kirim pesan, dan bermain game memiliki hubungan dengan terjadinya peningkatan status gizi, Sedangkan menggunakan internet untuk kegiatan akademik memiliki keterkaitan dengan penurunan berat badan. Berdasarkan pola yang ditemukan pada penelitian tersebut adiksi internet dapat mempengaruhi status gizi berdasarkan jenis aktivitas internet yang digunakan.

Seseorang yang adiksi internet dapat dipastikan terpapar oleh sinar biru, hal tersebut dapat menyebabkan gangguan pada durasi tidur (Harvard Health Letter, 2020). Semakin sedikit waktu tidur yang didapatkan oleh seseorang maka semakin meningkat risiko terjadinya peningkatan berat badan, begitu pula sebaliknya semakin lama waktu tidur yang didapatkan oleh seseorang maka semakin meningkat risiko penurunan berat badan (Grandner et al., 2015).

Menurut Kim et al (2018), pengguna yang kecanduan internet berisiko tinggi memiliki pola makan yang tidak teratur karena kehilangan nafsu makan, sering melewatkan makan malam dan memilih untuk melakukan snacking bila dibandingkan dengan yang tidak adiksi pada internet. Seseorang dengan adiksi internet berisiko tinggi tidak dapat memenuhi kebutuhan zat gizinya dikarenakan tidak cukup mengkonsumsi produk susu, daging, ikan, buah-buahan serta, sayuran dibandingkan dengan orang yang tidak adiksi pada internet. Asupan kalsium yang tidak mencukupi mempengaruhi proses pertumbuhan dan penting untuk mendapatkan massa tulang yang optimal dan memperbaiki jaringan tulang (Petrie, Stover, dan Horswill, 2004). Selain itu, seseorang dengan adiksi internet, konsumsi buah dan sayuran yang rendah berisiko tinggi akan kekurangan vitamin, mineral, dan serat. Vitamin dan mineral memiliki peran penting dalam pemeliharaan energi, pemeliharaan kesehatan, dan kekebalan tubuh yang dapat memberikan perlindungan tehadap stres oksidatif. Rerdapat penelitian telah menunjukkan bahwa asupan buah dan sayuran yang tepat bisa mencegah masalah kesehatan seperti obesitas dan penyakit kardiovaskular (Mirmiran et al., 2009).

Adiksi internet dapat membuat perubahan pola makan dapat menyebabkan tidak terpenuhinya kebutuhan zat gizi atau mengkonsumsi makanan secara berlebih. Pola makan yang berubah memungkinkan untuk mereka mengkonsumsi lebih dari jumlah harian yang direkomendasikan dari asupan zat gizi sepert lemak, garam, dan makanan tinggi gula sederhana. Asupan tinggi lemak dan gula sedehana dapat mengakibatkan kelebihan berat badan atau obesitas. Seseorang dengan kelebihan berat badan dapat mengalami permasalahan kesehatan yang merugikan seperti diabetes, hipertensi, dislipidemia, dan sindrom metabolisme (Kim et al., 2010). Perubahan pola makan pada orang yang mengalami adiksi internet juga memungkinkan untuk terjadinya malnutrisi atau asupan nutrisi yang tidak seimbang sehingga dapat menurunkan berat badan. Pada penelitian ini menemukan bahwa mahasiswa yang adiksi terhadap internet tidak dapat memenuhi kebutuhan zat gizi perharinya, hal tersebut dapat menyebabkan ketidak seimbangan asupan dan dapat mempengaruhi status gizinya. Berdasarkan pernyataan (Canan et al., 2014), penggunan internet berlebih memiliki 2,752 kali risiko terjadinya obesitas.

Seseorang dengan adiksi internet memiliki risiko tinggi mengkonsumsi alkohol dan merokok lebih banyak tibandingkan dengan yang tidak adiksi pada internet. Penelitian yang dilakukan oleh Malonda, Dinarti dan Pangastuti (2012). Ditemukan bahwa ada korelasi kuat antara kecanduan internet dan alkoholisme dan merokok. Ini karena perusahaan alkohol dan rokok menggunakan tema dan budaya populer, permainan online, kompetisi, situs web, dan iklan untuk mempromosikan produk mereka. Oleh karena itu, pengguna Internet sangat mungkin terpapar minuman beralkohol dan iklan rokok.Oleh karena itu, dibandingkan dengan pecandu internet, pecandu internet lebih cenderung memilih minum dan merokok daripada pecandu non-internet. Selain itu, frekuensi konsumsi minuman beralkohol dan merokok yang lebih tinggi pada seseorang yang adiksi pada internet dapat memperburuk pola makan. Meminum minuman beralkohol dan merokok berhubungan negatif dengan kualitas diet dan kebiasaan makan yang menyebabkan pola makan tidak teratur dan defisiensi gizi yang 
mempengaruhi status gizi masyarakat (Dube et al., 2013).

Berdasarkan penelitian yang dilakukan oleh (Rokhmah, Muniroh, dan Nindya, 2017), terdapat korelasi positif pada tingkat kecukupan zat gizi makro dengan status gizi seseorang. Pada penelitian lainnya oleh Muchilsa, Citrakesumasari dan Indrisari (2013) pada mahasiswi 189 Fakultas Kesehatan Masyarakat Universitas Hasanuddin Makasar menyatakan adanya korelasi yang signifikan antara energi $(p=<0,001)$, protein $(p=<0,001)$, lemak $(\mathrm{p}=0,002)$ dan karbohidrat $(\mathrm{p}=<0,001)$. Berdasarkan data yang didapatkan responden penelitian mayoritas memiliki tingkat kecukupan zat gizi yang kurang pada energi, lemak, dan karbohidrat. Maka dapat disimpulkan perbedaan hasil yang didapatkan disebabkan oleh tidak terpenuhinya kecukupan zat gizi dapat mengakibatkan penuunan berat badan sehingga tejadinya penurunan status gizi.

Penelitian yang dilakukan (Nisak, Permatasari, dan Setiawati, 2016) memperkuat pernyataan sebelumnya yang judulnya adalah hubungan masalah video game dengan perilaku, personal hygiene dan status gizi mahasiswa Jurusan Kedokteran dan Ilmu Kesehatan. Hasil penelitian menunjukkan bahwa penggunaan internet berlebih akan berdampak pada kesehatan. Terlalu lama berada di depan gawai untuk berinternet sering kali menyebabkan lupa makan, belajar, tidur, dan aktivitas lainnya. Oleh karena itu, seseorang dapat mengalami kurang gizi, karena tidak dapat memenuhi kebutuhan asupan zat gizi sehari, bahkan dapat menjadi gemuk karena kurannya aktivitas fisik yang dilakukan.

Anak - anak hingga orang dewasa menggunakan Internet sebagai sarana untuk memberi kompensasi dan mengatasi kekurangan dalam rasa percaya diri, identitas, dan hubungan. Secara umum, pecandu internet merasa sulit untuk menjalin hubungan intim dengan orang lain, dan sulit untuk menyembunyikan anonimitas dunia maya untuk menghubungi orang lain dengan cara yang tidak mengancam. Penggunaan internet sangat mendesak untuk mengatasi rasa rendah diri, rasa malu sosial, kesepian dan depresi.

Penelitian yang dilakukan (Rodgers et al., 2013) pada 60 perempuan pengidap eating disorders, prevalensi penggunaan internet secara kompulsif sebesar $11,7 \%$. Selanjutnya evaluasi yang dilakukan oleh Rodgers pada 392 mahasiswa dilaporkan seseorang dengan adiksi internet dan lebih lama meluangkan waktunya untuk daing memiliki hubungan eating disoder pada perempuan, namun tidak ada hubungan pada laki-laki. Oleh karena itu, seseoang yang adiksi pada internet memiliki resiko tinggi tejadinya eating disorder. Terjadinya eating disoder dapat mempengaruhi status gizi yang dikarenakan pola makan yang beubah.

\section{KESIMPULAN}

Penggunaan internet secara berlebih dapat mengakibatkan seseorang menjadi adiksi pada internet. Hasil dari penelitian ini menunjukkan bahwa terdapat korelasi negatif antara adiksi internet dengan status gizi Perubahan pola makan yang terjadi akibat adiksi internet adalah menurunnya nafsu makan, kebiasaan melewatkan waktu makan, dan mengemil. Oleh karena itu, Penggunaan internet sebaiknya dibatasi terutama pada area kampus dengan cara membatasi akses wi-fi gratis yang hanya dapat digunakan untuk kebutuhan studi, sehingga dapat mencegah terjadinya permasalahan kesehatan secara psikis dan fisik

Penelitian seperti ini juga sangat disarankan untuk penelitian kedepannya, dengan jumlah sampel yang lebih besar dan lebih banyak variabel terutama pada pola makan sehingga dapat menggambarkan secara lebih akurat.

\section{ACKNOWLEDGEMENT}

Terima kasih penulis sampaikan kepada dosen pembimbing, staf dan rekan-rekan Prodi Ilmu Gizi Universitas Airlangga yang telah memberikan dukungan dan bimbingan dalam menyelesaikan jurnal ini.

\section{REFERENSI}

Adriani, M. dan Wirjatmadi, B. (2012) Pengantar Gizi Masyarakat. Jakarta: Kencana.

Brown, J. (2019) Nutrition Through the Life Cycle. 7th edn. Boston: Cengage Learning.

Canan, F. et al. (2014) 'The Relationship Between Internet Addiction and Body Mass Index in Turkish Adolescents', Cyberpsychology, Behavior, and Social Networking, 17(1), pp. 40-45. doi: 10.1089/cyber.2012.0733.

Dube, S. R. et al. (2013) 'Smoking and Health-Related Quality of Life Among U.S. Adolescents', Nicotine \& Tobacco Research, 15(2), pp. 492-500. doi: 10.1093/ntr/nts 163.

Goldfield, G. S. et al. (2010) 'Body Dissatisfaction, Dietary Restraint, Depression, and Weight Status in Adolescents', Journal of School Health, 80(4), pp. 186-192. doi: 10.1111/j.1746-1561.2009.00485.x.

Grandner, M. A. et al. (2015) 'Relationship between sleep duration and body mass index depends on age', Obesity, 23(12), pp. 2491-2498. doi: 10.1002/oby.21247.

Kemp, S. (2020) Digital 2020 Global Digital Overview. Avaiable at: https://datareportal.com/reports/digital2020-global-digital-overview 
Khan, M. A., Shabbir, F. dan Rajput, T. A. (2017) 'Effect of Gender and Physical Activity on Internet Addiction in Medical Students', Pakistan Journal of Medical Sciences, 33(1). doi: 10.12669/pjms.331.11222.

Kim, S. Y. et al. (2018) 'Lack of sleep is associated with internet use for leisure', PLoS ONE, 13(1). doi: 10.1371/journal.pone.0191713.

Kim, Y. et al. (2010) 'The effects of Internet addiction on the lifestyle and dietary behavior of Korean adolescents', Nutrition Research and Practice, 4(1), pp. 51-57. doi: 10.4162/nrp.2010.4.1.51.

Kuss, D. J., Griffiths, M. D. dan Binder, J. F. (2013) 'Internet addiction in students: Prevalence and risk factors', Computers in Human Behavior, 29(3), pp. 959-966. doi: 10.1016/j.chb.2012.12.024.

Lajunen, H.-R. et al. (2007) 'Are computer and cell phone use associated with body mass index and overweight? A population study among twin adolescents', BMC Public Health, 7(1), p. 24. doi: 10.1186/1471-2458-724.

Lapousis, G. (2016) 'The Relation between Physical Activity and the use of Internet in Schoolchildren Aged 1315 Years Old', Swedish Jurnal Of Scientific Research, 3, pp. 1-7.

Letter, H. H. (2020) Blue light has a dark side.

Li, W. et al. (2016) 'Diagnostic Criteria for Problematic Internet Use among U.S. University Students: A MixedMethods Evaluation', PLOS ONE, 11(1), p. e0145981. doi: 10.1371/journal.pone.0145981.

Mak, K.-K. et al. (2014) 'Epidemiology of Internet Behaviors and Addiction Among Adolescents in Six Asian Countries', Cyberpsychology, Behavior, and Social Networking, 17(11), pp. 720-728. doi: 10.1089/cyber.2014.0139.

Malonda, N. swaninda, Dinarti, L.dan Pangastuti, R. (2012) 'Pola makan dan konsumsi alkohol sebagai faktor risiko hipertensi pada lansia', Jurnal Gizi Klinik Indonesia, 8(4), pp. 202-212.

Mirmiran, P. et al. (2009) 'Fruit and vegetable consumption and risk factors for cardiovascular disease', Metabolism, 58(4), pp. 460-468. doi: 10.1016/j.metabol.2008.11.002.

Muchilsa, Citrakesumasari dan Indrisari, R. (2013) 'Hubungan asupan zat gizi dengan status gizi pada remaja putri di Fakultas Kesehatan Masyarakat Universitas Hasanuddin Makassar Tahun 2013', Media Kesehatan Masyarakat Indonesia.

Murbawani, E. A. dan Firiana, L. (2017) 'Hubungan Persen Lemak Tubuh dan Aktifitas Fisik dengan Tingkat Kesegaran Jasmani Remaja Putri', JNH (Journal of Nutrition and Health), 5(2), pp. 69-84. doi: 10.14710/JNH.5.2.2017.69-84.

Naseri, L. et al. (2015) 'Perceived Social Support, Self-Esteem, and Internet Addiction Among Students of AlZahra University, Tehran, Iran', Iranian Journal of Psychiatry and Behavioral Sciences, 9(3). doi: 10.17795/ijpbs-421.

Nisak, K., Permatasari, E. dan Setiawati, herlia resti (2016) hubungan masalah video game dengan perilaku, personal hygiene dan status gizi mahasiswa Jurusan Kedokteran dan Ilmu Kesehatan.

Nova, M. dan Yanti, R. (2017) 'FAKTOR-FAKTOR YANG BERHUBUNGAN DENGAN OBESITAS PADA ORANG DEWASA DI KOTA PADANG PANJANG', Nutri-Sains: Jurnal Gizi, Pangan dan Aplikasinya, 1(1), p. 12. doi: 10.21580/ns.2017.1.1.1957.

Petrie, H. J., Stover, E. A. dan Horswill, C. A. (2004) 'Nutritional concerns for the child and adolescent competitor', Nutrition, 20(7-8), pp. 620-631. doi: 10.1016/j.nut.2004.04.002.

Poetry, M. (2019) Perbedaan Food Preference, Konsumsi Zat Energi dan Aktivitas Fisik Berdasarkan Status Gizi Mahasiswa Fakultas Kesehatan Masyarakat Universitas Airlangga. Universitas Airlangga.

Rinhard, E. et al. (2019) 'Hubungan Antara Kecanduan Internet Dengan Obesitas Pada Mahasiswa Kesehatan Masyarakat Universitas Sam Ratulangi', Jurnal Kesehatan Masyarakat Universitas Sam Ratulangi, 8(7), pp. 352-358.

Rodgers, R. F. et al. (2013) 'Internet Addiction Symptoms, Disordered Eating, and Body Image Avoidance', Cyberpsychology, Behavior, and Social Networking, 16(1), pp. 56-60. doi: 10.1089/cyber.2012.1570.

Rokhmah, F., Muniroh, L. dan Nindya, T. S. (2017) 'HUBUNGAN TINGKAT KECUKUPAN ENERGI DAN ZAT GIZI MAKRO DENGAN STATUS GIZI SISWI SMA DI PONDOK PESANTREN AL-IZZAH KOTA BATU', Media Gizi Indonesia, 11(1), p. 94. doi: 10.20473/mgi.v11i1.94-100.

Simanjuntak, N. (2020) Hubungan Antara Adiksi Internet Dengan Pola Makan Pada Mahasiswa Universitas HKBM Nommesen. Universitas HKBP Nommesen.

Soetjipto, H. P. (2015) 'Pengujian Validitas Konstruk Kriteria Kecanduan Internet', Jurnal Psikologi, 32(2), pp. $74-1$.

Thomala, L. L. (2021) China: internet user breakdown by age 2020.

Timur, D. J. (2019) Profil Kesehatan Jawa Timur Tahun 2018. Surabaya.

Widodo, B. . (2013) Tingkat Kesegaran Jasmani Pada Siswa SMP Negeri 2 Krembung dan SMP Negeri 2 Sidoarjo. Universitas Negeri Surabaya.

Wu, C.-Y. et al. (2015) 'Risk Factors of Internet Addiction among Internet Users: An Online Questionnaire Survey', PLOS ONE, 10(10), p. e0137506. doi: 10.1371/journal.pone.0137506. 
195 Media Gizi Kesmas, Vol. 10, No. 02 Desember 2021: Halaman : 187-195

Yang, S. (2001) 'Sociopsychiatric characteristics of adolescents who use computers to excess', Acta Psychiatrica Scandinavica, 104(3), pp. 217-222.

Young, K. (2017) Kecanduan Internet. 1st edn. Yogyakarta: Pustaka Belajar.

Zoer, I. et al. (2011) 'The associations between psychosocial workload and mental health complaints in different age groups', Ergonomics, 54(10), pp. 943-952. doi: 10.1080/00140139.2011.606920. 